\title{
The crustacean scavenger guild in Antarctic shelf, bathyal and abyssal communities
}

\author{
Claude De Broyer ${ }^{\mathrm{a}, *}$, Fabienne Nyssen ${ }^{\mathrm{a}, \mathrm{b}}$, Patrick Dauby ${ }^{\mathrm{a}, \mathrm{b}}$ \\ ${ }^{a}$ Institut Royal des Sciences Naturelles de Belgique, rue Vautier 29, B-1000 Brussels, Belgium \\ ${ }^{\mathrm{b}}$ MARE Centre - Oceanology, University of Liège, Sart Tilman B6, B-4000 Liège, Belgium
}

Received 28 December 2003; received in revised form 7 June 2004; accepted 28 June 2004

Available online 21 October 2004

\begin{abstract}
Peracarid crustaceans form a significant part of the macrobenthic community that is responsible for scavenging on large food falls onto the sea floor. Although several studies are available about scavengers from tropical and temperate seas, very little information has been published about such species living in Antarctic waters, particularly at greater depths. The present paper is based on a collection of 31 baited trap sets deployed in the Weddell Sea, Scotia Sea, and off the South Shetland Islands, and presents results on the geographical and bathymetric distribution of the different taxa and on the eco-functional role of scavengers.

Some 68,000 peracarid crustaceans from 62 species were collected. About $98 \%$ of individuals belonged to the amphipod superfamily Lysianassoidea, and $2 \%$ to the isopod family Cirolanidae. Of these species, 31, including 26 lysianassoids (1400 individuals), were collected deeper than $1000 \mathrm{~m}$.

High species richness was discerned for the eastern Weddell Sea shelf compared with other Antarctic areas. The Antarctic slope also seems to be richer in species than other areas investigated in the world, while in the abyss, scavenger species richness appears to be lower in Antarctica. A richness gradient was thus observed from the shelf to the deep. For amphipods, a number of species extend their distribution from the shelf to the slope and only one to the abyssal zone.

Amphipod species showed degrees of adaptation to necrophagy. The functional adaptations of the mandible and the storage function of the gut are discussed. Feeding experiments conducted on lysianassoid species collected at great depths and maintained in aquaria showed a mean feeding rate of about $1.4-4.1 \%$ dry body weight day ${ }^{-1}$, which is consistent with data obtained from other species.
\end{abstract}

(C) 2004 Elsevier Ltd. All rights reserved.

\footnotetext{
${ }^{*}$ Corresponding author. Tel.: +32-2-62-74-127; fax: +32-262-74-277.

E-mail address: claude.debroyer@naturalsciences.be (C. De Broyer).
}

\section{Introduction}

The scavenger guild plays a key role in deep-sea benthic communities by rapid recycling and dispersing organic falls of all sizes, from small 
plankters to whales (e.g., Gage and Tyler, 1991; Britton and Morton, 1994).

In the Antarctic seas, the existence of an abundant and active scavenger fauna was noticed by early Antarctic marine investigators. Observing the large catch of lysianassid amphipods attracted quickly to baited nets at Cape Adare during the National Antarctic Expedition 1901-1904, Hodgson (in Walker, 1907) wrote:

The trap contained about 10,000 of these amphipods...Four fish were in the trap, one of them had been reduced to an absolute skeleton; on another the amphipods hung by their 'teeth' in a compact mass, completely concealing their victim. Its skin had disappeared, and I judged also a millimetre of flesh... the other two fish were presumably waiting their turn.

These early collections were mostly opportunistic. With the establishment of permanent coastal Antarctic stations, baited traps have been used more systematically to collect necrophagous invertebrates (e.g., Hurley, 1965; Arnaud, 1970; Bruchhausen et al., 1979; Rakusa-Suszczewski, 1982; Nagata, 1986; Presler, 1986; Slattery and Oliver, 1986; Moore, 1994). These catches have provided data on the composition, ecology and biology of scavengers, as well as the discovery of species new to science (e.g., Hurley, 1965; De Broyer, 1985a; Nagata, 1986). Most of this sampling was done at depths shallower than $150 \mathrm{~m}$. Attempts to collect scavengers on the deep Antarctic continental shelf, which extends to an average depth of $450 \mathrm{~m}$ and, in places, to over $1000 \mathrm{~m}$ depth (Clarke and Johnston, 2003), have been relatively few (Arnaud, 1970; De Broyer and Klages, 1990; De Broyer et al., 1997, 1999; Takeuchi et al., 2001).

Baited trap sampling led to the discovery of an unexpected vagile benthic fauna of fish and crustaceans under the Ross Ice Shelf at a distance of $400 \mathrm{~km}$ from the sea, under ice $415 \mathrm{~m}$ thick (Bruchhausen et al., 1979; Lipps et al., 1979; Stockton, 1982).

In the deep sea, bathyal and abyssal trap sampling was initiated by the Prince of Monaco as early as 1888 and provided new, and sometimes giant, species of crustaceans and fishes (Richard, 1934; Chevreux, 1935; De Broyer and Thurston, 1987). Much later, baited cameras revealed the existence of a very active guild of mobile necrophages in the deep sea, which attracted much interest (e.g., Isaacs and Schwartzlose, 1975; Hessler et al., 1978; Gage and Tyler, 1991; Britton and Morton, 1994). In the Antarctic deep sea, attempts at baited trap collecting have, so far, been extremely few: two operations were reported by Bowman and Manning (1972) from north of Amundsen Sea at depths of 4930 and $5045 \mathrm{~m}$ and one single operation at $3186 \mathrm{~m}$ off Queen Maud Land was undertaken by Takeuchi et al. (2001).

During the Polarstern EASIZ campaigns (1996, 1998) in the Weddell Sea, baited traps were used systematically to complement the catches made by other gears in order to obtain a more complete representation of the shelf and slope assemblages at the so-called "integrated stations" (Arntz and Gutt, 1997, 1999; De Broyer et al., 1997, 1999). These trap operations collected mobile scavengers (sometimes in large number) that were not, or only rarely, sampled by other gears such as trawls, dredges, epibenthic sledges, box-corers and deep plankton nets.

In addition, investigations of the Antarctic deep sea have recently been conducted during the Polarstern ANDEEP cruises in 2002 in the Scotia Sea, the western Weddell Sea and the South Sandwich Trench (Brandt et al., 2003; De Broyer et al., 2003). These bathyal and abyssal investigations involved a series of successful deep-sea trapping operations.

The results of these Polarstern campaigns in terms of composition and bathymetric distribution of the crustacean scavenger guild are reported herein and Antarctic shelf and deep sea faunules are compared. In addition, to investigate the role of the scavenger guild in Antarctic shelf communities and to complement data previously obtained from gut content analyses (Dauby et al., 2001a, b), results of feeding experiments on necrophagous amphipods are presented.

\section{Material and methods}

\subsection{The autonomous trap system}

All scavengers were sampled using an "autonomous trap system" (ATS), based on the system 
developed at IFREMER, Brest (Guennegan and Martin, 1985). It consists of four elements (Fig. 1):

1. A brass trapezoidal frame (about $1 \mathrm{~m}^{3}$ ) on which are fixed various baited traps, either in direct contact with the bottom or held $1 \mathrm{~m}$ above. "Box traps" are metal rectangular frames of different sizes (7 or 221), covered with nylon gauze of $500 \mu \mathrm{m}$, with two inverse conical openings (diameter: 2 or $4 \mathrm{~cm}$ ). Their upper side can be opened for rapid retrieval of collected animals.

2. A buoyancy package made of sets of highpressure $10^{\prime \prime}$ or 17 " glass balls (50 and $260 \mathrm{~N}$ buoyancy, respectively) attached directly to the frame and a few metres above it.

3. A deep-sea acoustic release (Ix-Sea Oceano Instruments, Brest, France).

4. Disposable ballast made of iron plate and anchor chains.

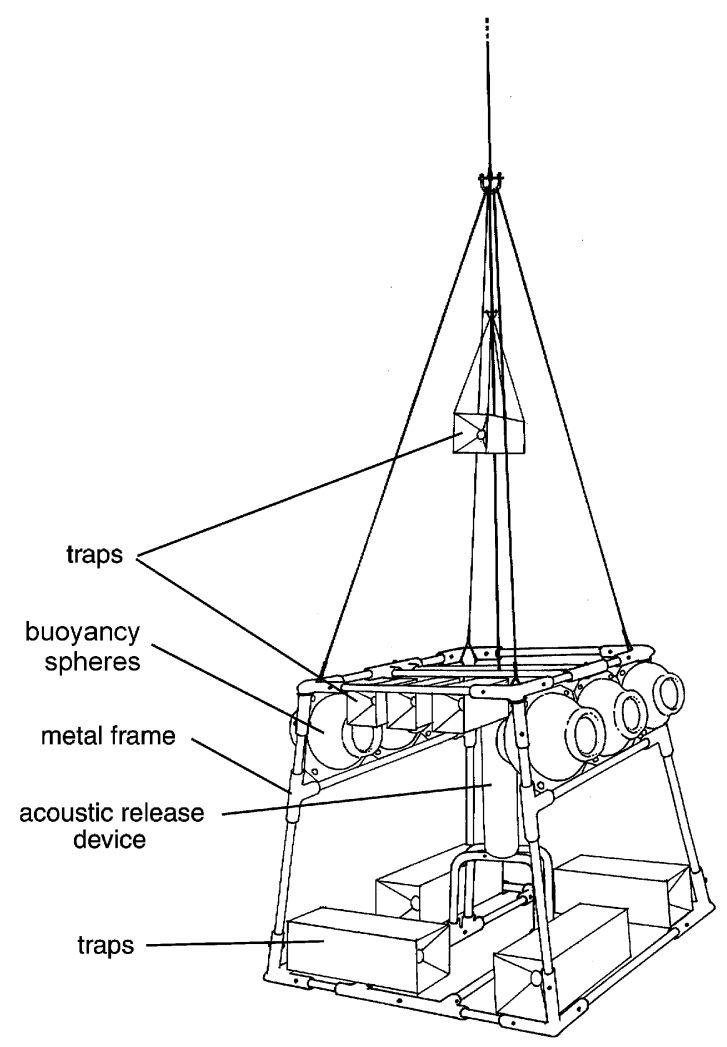

Fig. 1. The autonomous trap system.
Traps were baited (preferably) with notothenioid fish when available, or with other fish or beef meat (from about 200 to $600 \mathrm{~g}$, depending on trap size). Bait was usually wrapped in nets $(5 \mathrm{~mm}$ mesh) in order to prevent too rapid consumption and so increase the time over which it remained attractive. The system was deployed and retrieved after 1-5 days (preferably $48 \mathrm{~h}$ ) on the bottom (Table 1). A low-frequency acoustic signal sent from the ship activated release of the ballast and the ATS was returned to the surface by the buoyancy.

The ATS has provided healthy individuals of necrophagous species that could be reared in aquaria and kept alive for as long as 2 years.

\subsection{Sampling sites}

The material was collected with the ATS during several cruises of the German icebreaker Polarstern in the Southern Ocean:

- Two deployments (using classical line mooring traps) during the EPOS leg 3 cruise, JanuaryFebruary 1989, in the eastern Weddell Sea (De Broyer and Klages, 1990).

- Six deployments during the EASIZ I cruise, January-March 1996, in the eastern Weddell Sea (De Broyer et al., 1997).

- 15 deployments during the EASIZ II cruise, January-March 1998, in the eastern Weddell Sea and off South Shetland Islands (De Broyer et al., 1999). In addition to ATS catches, two samples were collected from a classical fish trap, at stations 152 and 266.

- Six deployments during the cruises ANDEEP 1 and ANDEEP 2, January-March 2002, in the southern Drake Passage, the western Weddell Sea and the Scotia Sea (De Broyer et al., 2003).

Sampling data are presented in Table 1 and sampling locations are shown in Fig. 2.

\subsection{Feeding experiments}

Directly after collection, animals were transferred to a cool laboratory (maintained at $-1 \pm 1{ }^{\circ} \mathrm{C}$ ), sorted by species and counted. They 
Table 1

Station data for 29 autonomous trap system operations and two fish traps

\begin{tabular}{|c|c|c|c|c|c|c|c|c|}
\hline \multirow[t]{2}{*}{ Cruise } & \multirow[t]{2}{*}{ Station } & \multirow[t]{2}{*}{ Date } & \multirow[t]{2}{*}{ Area } & \multicolumn{2}{|l|}{ Location } & \multirow{2}{*}{$\begin{array}{l}\text { Depth } \\
(\mathrm{m})\end{array}$} & \multirow{2}{*}{$\begin{array}{l}\text { Soak time } \\
\text { (h) }\end{array}$} & \multirow{2}{*}{$\begin{array}{l}\text { Number of } \\
\text { specimens }\end{array}$} \\
\hline & & & & ${ }^{\circ} \mathrm{S}$ & ${ }^{\circ} \mathrm{W}$ & & & \\
\hline \multirow[t]{2}{*}{ EPOS } & 228 (T2) & 28.01 .89 & Halley Bay & $75^{\circ} 14.4^{\prime}$ & $26^{\circ} 42.1^{\prime}$ & 399 & 70 & 3500 \\
\hline & 275 (T4) & 15.02 .89 & Kapp Norvegia & $71^{\circ} 39.5^{\prime}$ & $12^{\circ} 04.4^{\prime}$ & 236 & 50 & \\
\hline \multirow[t]{6}{*}{ EASIZ I } & 04 (T4) & 20.02 .96 & Kapp Norvegia & $71^{\circ} 40.6^{\prime}$ & $12^{\circ} 31.0^{\prime}$ & 421 & 132 & 2924 \\
\hline & $05(\mathrm{~T} 1)$ & 06.02 .96 & Kapp Norvegia & $71^{\circ} 40.2^{\prime}$ & $12^{\circ} 45.3^{\prime}$ & 223 & 23 & 576 \\
\hline & 06 (T2) & 07.02 .96 & Kapp Norvegia & $71^{\circ} 31.5^{\prime}$ & $13^{\circ} 31.4^{\prime}$ & 234 & 74 & 2619 \\
\hline & 12 (T3) & 13.02 .96 & Vestkapp & $73^{\circ} 15.7^{\prime}$ & $21^{\circ} 04.8^{\prime}$ & 791 & 65 & 769 \\
\hline & 28 (T5) & 26.02 .96 & Kapp Norvegia & $71^{\circ} 29.6^{\prime}$ & $12^{\circ} 21.2^{\prime}$ & 219 & 74 & 2848 \\
\hline & $30(T 6)$ & 01.03 .96 & Atka Bay & $70^{\circ} 01.0^{\prime}$ & $08^{\circ} 16.5^{\prime}$ & 2009 & 86 & 818 \\
\hline \multirow[t]{17}{*}{ EASIZ II } & $11 / 25(\mathrm{~T} 1)$ & 26.01 .98 & Drescher Inlet & $72^{\circ} 50.8^{\prime}$ & $19^{\circ} 55.5^{\prime}$ & 377 & 38 & 25365 \\
\hline & $27 / 76$ (T2) & 28.01 .98 & Kapp Norvegia & $71^{\circ} 19.0^{\prime}$ & $12^{\circ} 24.2^{\prime}$ & 171 & 103 & 10528 \\
\hline & 38/75 (T3) & 29.01 .98 & Kapp Norvegia & $70^{\circ} 59.0$ & $11^{\circ} 09.1$ & 389 & 82 & 765 \\
\hline & $094 / 119$ (T4) & 05.02 .98 & Vestkapp & $73^{\circ} 35.7^{\prime}$ & $22^{\circ} 23.4^{\prime}$ & 813 & 50 & 788 \\
\hline & $102 / 122(\mathrm{~T} 5)$ & 05.02 .98 & Vestkapp & $73^{\circ} 36.0^{\prime}$ & $22^{\circ} 00.5^{\prime}$ & 396 & 46 & 516 \\
\hline & $138 / 155$ (T6) & 09.02 .98 & Halley Bay & $74^{\circ} 39.8^{\prime}$ & $27^{\circ} 13.1^{\prime}$ & 798 & 39 & 3434 \\
\hline & $152(\mathrm{FT})$ & 11.02 .98 & Halley Bay & $74^{\circ} 36.8^{\prime}$ & $26^{\circ} 53.9^{\prime}$ & 597 & & \\
\hline & $160 / 179(\mathrm{~T} 7)$ & 11.02 .98 & Halley Bay & $74^{\circ} 40.0^{\prime}$ & $26^{\circ} 57.9^{\prime}$ & 403 & 38 & 4188 \\
\hline & $202 / 233$ (T8) & 18.02 .98 & Kapp Norvegia & $70^{\circ} 57.0^{\prime}$ & $11^{\circ} 40.6^{\prime}$ & 808 & 58 & 401 \\
\hline & 203/234 (Т9) & 18.02 .98 & Kapp Norvegia & $70^{\circ} 58.8^{\prime}$ & $11^{\circ} 39.4^{\prime}$ & 442 & 58 & 787 \\
\hline & $251 / 267$ T10) & 22.02 .98 & Drescher Inlet & $72^{\circ} 47.8^{\prime}$ & $19^{\circ} 31.4^{\prime}$ & 895 & 66 & 1820 \\
\hline & $255 / 268(T 11)$ & 23.02 .98 & Drescher Inlet & $72^{\circ} 48.4^{\prime}$ & $19^{\circ} 39.6^{\prime}$ & 1453 & 58 & 1642 \\
\hline & $266(\mathrm{FT})$ & 25.02 .98 & Drescher Inlet & $72^{\circ} 50.5^{\prime}$ & $19^{\circ} 21.8^{\prime}$ & 419 & & \\
\hline & $279 / 283(T 12)$ & 28.02 .98 & Atka Bay & $70^{\circ} 24.1^{\prime}$ & $07^{\circ} 52.2^{\prime}$ & 1136 & 48 & 75 \\
\hline & $280 / 284$ (T13) & 28.02 .98 & Atka Bay & $70^{\circ} 27.4^{\prime}$ & $07^{\circ} 55.9^{\prime}$ & 550 & 48 & 2085 \\
\hline & 291/312 (T14) & 14.03 .98 & King George Island & $62^{\circ} 16.6^{\prime}$ & $58^{\circ} 15.8^{\prime}$ & 798 & 57 & 451 \\
\hline & $292 / 315$ (T15) & 14.03 .98 & King George Island & $62^{\circ} 11.3^{\prime}$ & $58^{\circ} 20.2^{\prime}$ & 414 & 58 & \\
\hline \multirow[t]{4}{*}{ ANDEEP 1} & 46 & 29.01 .02 & Elephant Island & $60^{\circ} 39^{\prime}$ & $53^{\circ} 59^{\prime}$ & 2926 & 14 & 44 \\
\hline & 83 & 07.02 .02 & Elephant Island & $61^{\circ} 07^{\prime}$ & $56^{\circ} 09^{\prime}$ & 349 & 72 & 8597 \\
\hline & 100 & 13.02 .02 & King George Island & $61^{\circ} 25^{\prime}$ & $58^{\circ} 54^{\prime}$ & 2280 & 57 & 171 \\
\hline & 114 & 17.02 .02 & King George Island & $61^{\circ} 46^{\prime}$ & $60^{\circ} 45^{\prime}$ & 2754 & 54 & 36 \\
\hline \multirow[t]{2}{*}{ ANDEEP 2} & 131 & 05.03 .02 & $N-W$ Weddell Sea & $65^{\circ} 19^{\prime}$ & $51^{\circ} 35^{\prime}$ & 3070 & 71 & 129 \\
\hline & 139 & 19.03 .02 & South Sandwich Trench & $58^{\circ} 18^{\prime}$ & $24^{\circ} 29^{\prime}$ & 3739 & 71 & 1000 \\
\hline
\end{tabular}

Italic rows correspond to stations deeper than $1000 \mathrm{~m}$.

were then distributed, by groups of 40-150, among different aquaria (15-2001) continuously provided with clean fresh sea water.

Several experiments were performed in order to evaluate the feeding rate of four common scavenging Antarctic amphipod species (all lysianassoids, see Table 6). Animals were starved for periods of 9-15 days to maximise foregut clearance (as checked from dissected individuals). During this fast, faeces and exuvia were removed daily. After starvation, weighed (and calibrated for dry vs. wet weight) food items (pieces of squid or fish) were given ad lib every day during experiments lasting 7-29 days. Uneaten food was removed after $24 \mathrm{~h}$, oven-dried and weighed, enabling calculation of mean daily ingestion rates. At the end of the last day of experiment, amphipods were sacrificed and oven-dried to obtain their mean invidual weight. Results are expressed as $\mathrm{g}_{\text {food-DW }} \mathrm{g}_{\text {animal-DW }}^{-1} \mathrm{day}^{-1} \times$ $100\left(\right.$ or $\%$ day $^{-1}$ ).

Egestion rates were estimated, in parallel to some feeding experiments, with Waldeckia obesa 


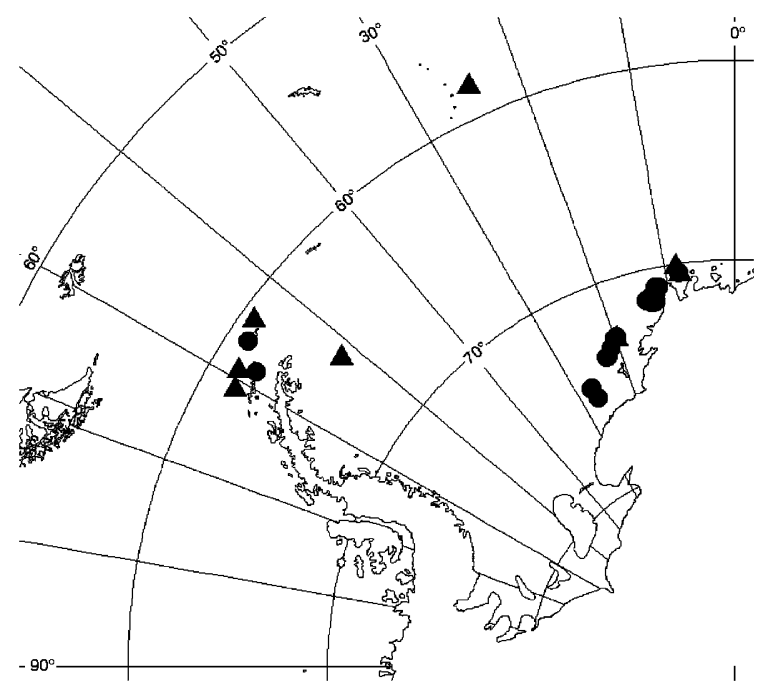

Fig. 2. Location of the 29 trap deployments. Circles and triangles indicate stations lower and deeper than $1000 \mathrm{~m}$, respectively.

(Chevreux, 1905). After a single 24-h feeding period, a group of animals was placed in nylon gauze baskets (mesh size $2 \mathrm{~mm}$ ) that allowed faecal pellets to pass through, so to avoid coprophagy. Animals were kept unfed for 5-9 days, and faeces were collected twice daily, dried and weighed as above.

\section{Results and discussion}

\subsection{Sampling methodology}

The ATS is a sampling device that collects roughly "what is scavenging around", i.e. the necrophagous organisms able to detect and track the bait odour and living at a distance corresponding to the food odour plume in the water, itself influenced by the direction and velocity of the local bottom current (Sainte-Marie and Hargrave, 1987). Several factors, such as bottom topography and related benthic biological community structure, are likely to affect the number and composition of the fauna attracted to bait. Sample size and composition not only depend on these environmental factors, but also on structural ones related to the trap design (mouth opening, mesh size) and relative position of the trap on or above the sea floor. Finally, bait quality and type may attract preferentially some species. The duration of trap deployment has been reported to influence the number of individuals caught, at least initially, when a positive correlation is found (Stockton, 1982). However, in our study there was no relationship between the number of individuals or species and soak time for ATS deployments ranging from about $10-135 \mathrm{~h}$ (Fig. 3). Possible causes include escape from traps, bait exhaustion, interspecific predation or cannibalism inside the traps (behaviours we observed in restricted aquarium conditions), tidal effects, or simply the local density of the scavenging fauna. Thus the ATS can be considered at best only a semi-qualitative sampler.

\subsection{Composition of the scavenger guild}

The 31 trap sets reported here captured a total of about 70,000 invertebrates from 76 species and 10 specimens of fish from four species (Table 2).

Twenty-one trap sets at shelf depths (less than $1000 \mathrm{~m}$ ) in the eastern Weddell Sea and around South Shetland Islands captured more than 68,000 specimens of crustaceans belonging to 53 benthic and benthopelagic species, five specimens of echinoderms and seven specimens of three fish species.

In the deep sea, eight trap operations on the slope of the eastern Weddell Sea and at bathyal and abyssal depths in the western Weddell Sea, the Scotia Sea and the South Sandwich Trench provided about 1400 crustaceans of 33 species, one specimen of a gastropod and three specimens of fish.

While the trap samples can be considered representative of the crustacean scavenger fauna, this is not the case for the fish, as the traps were suboptimal in terms of size and entrance diameter for collecting them.

Both at shelf depth and in the deep sea (slope and abyssal plain) the bulk of the catches consisted of amphipod crustaceans, in particular lysianassoids. The second dominant group, the cirolanid isopods, was not represented significantly in the deep-sea samples. A few representatives of other 

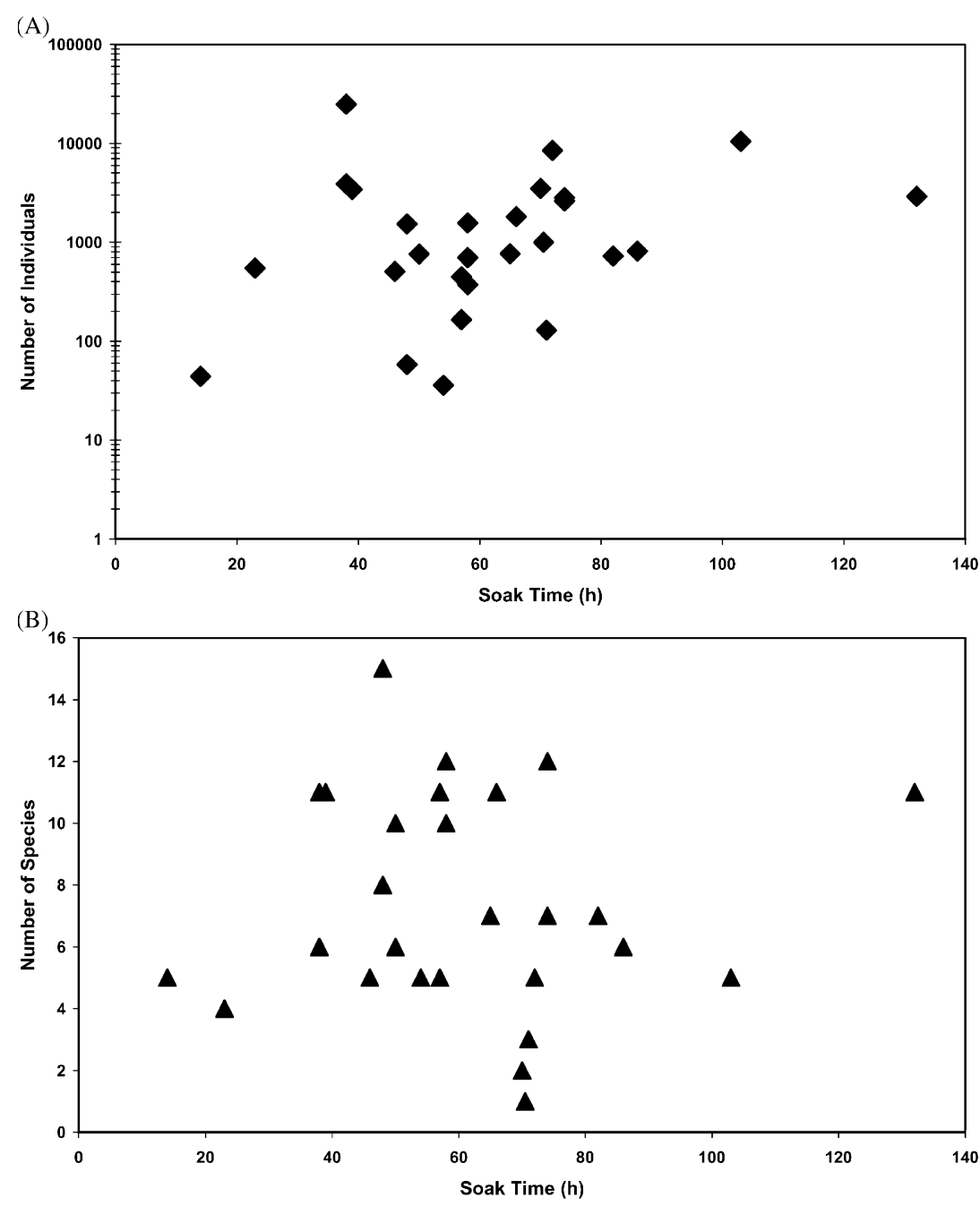

Fig. 3. Numbers of collected individuals (A) and species (B) vs. soak time of the autonomous trap system.

amphipod families (Epimeriidae, Iphimediidae, Eusiridae, Melphidippidae, Stegocephalidae) were collected as well as other crustacean groups, namely Leptostraca, Ostracoda, Copepoda, Mysidacea and Decapoda.

The detailed taxonomic composition of the amphipods collected is presented in Tables 3 and 4. Complete taxonomic references and zoogeographical characterisation of the species can be found in De Broyer and Jazdzewski (1993). Within the very diverse superfamily Lysianassoidea, species have been allocated to the different family groups recognised by a recent cladistic analysis
(Lowry, pers. comm.). On the shelf, a total of 37 lysianassoid species have been collected belonging to 17 different genera. Lysianassoid amphipods are known to comprise a number of scavenger species (e.g., Thurston, 1990; Lowry and Stoddart, 1989, 1994). Representatives of Adeliella and Allogaussia were taken in traps for the first time but may be accidental (one unique specimen in each case). Part of the collected species remains to be precisely identified. One new species has been found in each of the genera Allogaussia, Paracallisoma, Pseudorchomene, Stephonyx and Tryphosella. 
Table 2

Comparison between the number of species and individuals of the different taxonomic groups collected by the autonomous trap system and fish traps at shelf and deep-sea depths

\begin{tabular}{|c|c|c|c|}
\hline \multirow{5}{*}{$\begin{array}{l}\text { Campaign } \\
\text { Locality }\end{array}$} & \multirow{5}{*}{$\begin{array}{l}\text { Antarctic shelf }(<1000 \mathrm{~m}) \\
\text { EPOS/EASIZ I and II } \\
\text { Eastern Weddell Sea }\end{array}$} & \multicolumn{2}{|c|}{ Antarctic deep sea $(>1000 \mathrm{~m})$} \\
\hline & & EASIZ & ANDEEP \\
\hline & & Eastern Weddell Sea & South Shetland Islands \\
\hline & & South Shetland Islands & Scotia Sea \\
\hline & & & South Sandwich Trench \\
\hline \multirow{3}{*}{$\begin{array}{l}\text { Depth range } \\
\text { No. of trap operations }\end{array}$} & $171-895 \mathrm{~m}$ & $1139-2009 \mathrm{~m}$ & $2280-3739 \mathrm{~m}$ \\
\hline & 20 & 3 & 5 \\
\hline & No. of spp (No. of ind.) & No. of spp (No. of ind.) & \\
\hline \multicolumn{4}{|l|}{ CRUSTACEA } \\
\hline \multicolumn{4}{|l|}{ Amphipoda } \\
\hline Lysianassoidea & $37(\sim 65000)$ & $26(1374)$ & \\
\hline Iphimedioidea & $2(4)$ & $2(2)$ & \\
\hline Eusiridae & $2(7)$ & & \\
\hline Melphidippidae & $1(1)$ & & \\
\hline Stegocephalidae & & $2(3)$ & \\
\hline \multicolumn{4}{|l|}{ Isopoda } \\
\hline Cirolanidae & $3(1547)$ & $1(4)$ & \\
\hline Leptostraca & $2(23)$ & & \\
\hline Ostracoda & $2(1500)$ & & \\
\hline Copepoda & $2(4)$ & $2(2)$ & \\
\hline Mysidacea & $1(13)$ & & \\
\hline Decapoda & $1(1)$ & & \\
\hline \multicolumn{4}{|l|}{ MOLLUSCA } \\
\hline Gastropoda & & $1(1)$ & \\
\hline \multicolumn{4}{|l|}{ ECHINODERMATA } \\
\hline Asteroidea & $1(1)$ & & \\
\hline Ophiuroidea & $3(4)$ & & \\
\hline PISCES & $3(7)$ & $3(3)$ & \\
\hline
\end{tabular}

In the deep sea, 26 lysianassoid species from 15 genera were found, with one new species in each of the following genera: Alicella, Hirondellea, Orchomenopsis, Paralicella and "Tryphosella" in addition to the four new species occurring also in the shelf zone.

Single species of Epimeriidae and Iphimediidae have been found in each depth zone. There is no previous record of Epimeriidae in baited traps except for Epimeria cf cornigera (Jones et al., 2003) and Epimeria similis (Dauby et al., 2001a). Stomach content analysis of the latter species by the same authors revealed the presence of various food items such as cnidocysts of hydrozoans and actiniids, sponge spicules, polychaete setae and planktonic cells (diatoms and foraminifers), but also of pieces of fish flesh in individuals captured in traps. Iphimediidae have never been taken in baited traps and their trophic ecology generally characterises them as being specialist micropredators (Coleman, 1989a, b; Dauby et al., 2001a). They were probably caught accidentally in traps.

Few Eusiridae are regular scavengers (e.g., Chevreux, 1935; Vader, 1972; Bowman, 1974). Some Eusirus species have been recorded in traps in Admiralty Bay, King George Island (De Broyer, unpublished) and on the shelf off Enderby Land (Takeuchi et al., 2001). Examination of feeding 
Table 3

Amphipod species collected with the autonomous trap system and fish traps at depths shallower than $1000 \mathrm{~m}$; occurrence by station and depth ranges

EPOS EASIZ I EASIZ II Depth range

\section{LYSIANASSOIDEA}

Lysianassidae and Uristidae

Abyssorchomene charcoti (Chevreux, 1912)

Abyssorchomene nodimanus (Walker, 1903)

Abyssorchomene plebs (Hurley, 1965)

Abyssorchomene rossi (Walker, 1903)

Adeliella sp.A

Allogaussia n.sp.1

Cheirimedon crenatipalmatus (Stebbing, 1888)

Hippomedon sp.A

Orchomenopsis cavimanus (Stebbing, 1888) var.A

Orchomenopsis kryptopinguides (Andres, 1983)

Orchomenopsis pinguides (Walker, 1903)

Parschisturella carinata (Schellenberg, 1926)

Pseudorchomene coatsi (Chilton, 1912)

Pseudorchomene n.sp.1

Stephonyx n.sp.1

Tryphosella cf analogica (K.H. Barnard, 1932)

Tryphosella bispinosa (Schellenberg, 1931)

Tryphosella intermedia (Schellenberg, 1926)

Tryphosella longiseta (Ren, 1991)

Tryphosella macropareia (Schellenberg, 1926)

Tryphosella murrayi (Walker, 1903)

Tryphosella n.sp.1

Tryphosella sp.A

Tryphosella sp.B

Tryphosella sp.C

Tryphosella sp.D

Tryphosella sp.E

Tryphosella sp.F

Tryphosella sp.G

"Tryphosella" cicadopsis (Schellenberg, 1926)

"Tryphosella" n.sp. 2

Uristes gigas (Dana, 1849)

Uristes stebbingi (Walker, 1903)

Waldeckia obesa (Chevreux, 1905)

Eurytheneid family group

Eurythenes gryllus (Lichtenstein, 1822)

Hirondelleid family group

Hirondellea antarctica (Schellenberg, 1926)

\section{Scopelocheiridae}

Paracallisoma n.sp.1

IPHIMEDIOIDEA

Epimeriidae

Epimeria similis (Chevreux, 1912)

\section{Iphimediidae}

Iphimediella bransfieldi (K.H. Barnard, 1932)

\begin{tabular}{|c|c|c|c|}
\hline & $\mathrm{T} 2$ & & 234 \\
\hline $\mathrm{T} 4$ & $\mathrm{~T} 2-4-5$ & $\mathrm{~T} 2-4-13$ & $171-813$ \\
\hline \multirow[t]{8}{*}{$\mathrm{T} 2$} & & Т1-5-7-13-14-15 & $377-798$ \\
\hline & $\mathrm{T} 4-5$ & $\mathrm{~T} 1-7-9-13$ & $219-550$ \\
\hline & & 152 & 597 \\
\hline & & $\mathrm{T} 4$ & 813 \\
\hline & $\mathrm{T} 3$ & 152 & $389-597$ \\
\hline & $\mathrm{T} 2-5$ & T6-7-8-9-10-13, 152 & $219-895$ \\
\hline & $\mathrm{T} 4-5$ & $\mathrm{~T} 1$ to $10,13-14, \mathbf{1 5 2}$ & $171-895$ \\
\hline & & $\mathrm{T} 3$ & 389 \\
\hline \multirow[t]{2}{*}{$\mathrm{T} 4$} & $\mathrm{~T} 2-5$ & $\mathrm{~T} 2-7$ & $171-403$ \\
\hline & $\mathrm{T} 1-2-3-4-5$ & T3-4-5-6-8-10, 152 & $219-895$ \\
\hline \multirow[t]{8}{*}{$\mathrm{T} 4$} & $\mathrm{~T} 4-5$ & $\mathrm{~T} 1$ to $10,13-14-15, \mathbf{2 6 6}$ & $171-895$ \\
\hline & & $\mathrm{T} 4-6-10$ & $798-895$ \\
\hline & $\mathrm{T} 3$ & $\mathrm{~T} 4-6-8-10-13$ & $791-895$ \\
\hline & $\mathrm{T} 3$ & T6-10 & $791-895$ \\
\hline & $\mathrm{T} 2$ & & 234 \\
\hline & & T6-7-8-9-10, 152 & $403-895$ \\
\hline & & $\mathrm{T} 8$ & 808 \\
\hline & $\mathrm{T} 4$ & $\mathrm{~T} 4-8$ & $421-813$ \\
\hline \multirow[t]{12}{*}{$\mathrm{T} 4$} & T1-2-4 & T1-3-7-9-10-13, 266 & $223-895$ \\
\hline & & T6 & 798 \\
\hline & & $\mathrm{T} 4$ & 813 \\
\hline & & $\mathrm{T} 7$ & 403 \\
\hline & & $\mathrm{T} 7$ & 403 \\
\hline & & T9 & 442 \\
\hline & $\mathrm{T} 2-3$ & & $234-791$ \\
\hline & $\mathrm{T} 4$ & & 421 \\
\hline & $\mathrm{T} 4$ & & 421 \\
\hline & & T7-9-13 & $403-550$ \\
\hline & & T6-13, 152 & $550-798$ \\
\hline & & $\mathrm{T} 13, \mathbf{1 5 2}$ & $550-597$ \\
\hline $\mathrm{T} 4$ & $\mathrm{~T} 2$ & $\mathrm{~T} 2-4$ & $171-813$ \\
\hline \multirow[t]{6}{*}{$\mathrm{T} 2-4$} & $\mathrm{~T} 1-2-3-4-5$ & $\mathrm{~T} 1,3$ to $10,13, \mathbf{1 5 2}$ & $219-895$ \\
\hline & $\mathrm{T} 3$ & $\mathrm{~T} 13-14$ & $550-798$ \\
\hline & $\mathrm{T} 1-2-3$ & T8-13, 152 & $223-808$ \\
\hline & & $\mathrm{T} 14$ & 451 \\
\hline & & $\mathrm{T} 10-13, \mathbf{1 5 2}$ & $550-895$ \\
\hline & & 266 & 419 \\
\hline
\end{tabular}


Table 3 (continued)

\begin{tabular}{|c|c|c|c|c|}
\hline & EPOS & EASIZ I & EASIZ II & Depth range \\
\hline \multicolumn{5}{|l|}{ EUSIROIDEA } \\
\hline \multicolumn{5}{|l|}{ Eusiridae } \\
\hline Eusirus cf antarcticus (Thomson, 1880) & & T2-5 & T3-9, 152 & 219-597 \\
\hline Eusirus bouvieri (Chevreux, 1911) & & $\mathrm{T} 4$ & $\mathrm{~T} 7$ & $403-421$ \\
\hline \multicolumn{5}{|l|}{ Melphidippidae } \\
\hline Melphidippa antarctica (Schellenberg, 1926) & & & 152 & 597 \\
\hline
\end{tabular}

behaviour and stomach contents showed that $E$. cf antarcticus, for instance, is a selective macropredator able to feed partially on carrion (Dauby et al., 2001a).

Melphidippa antarctica is a passive suspension feeder (Dauby et al., 2001a) and the unique specimen was quite probably collected accidentally in trap.

Stegocephalidae are mostly micropredators associated with diverse benthic sessile invertebrates, while some species have been reported to be occasional scavengers (Berge and Vader, 2003). They are, however, not taken commonly in traps except for some species of Andaniotes and Austrocephaloides (Berge and Vader, 2001; Berge, pers. comm.). Takeuchi et al. (2001) found Parandania boecki (Stebbing, 1888) and Euandania gigantea (Stebbing, 1883) in their abyssal trap off Enderby Land. Both species are meso- or bathypelagic and rarely, if ever, taken in baited traps. Some specimens of Euandania were alsofound by Thurston (pers. comm.) in bathyal and abyssal trap catches in the Atlantic Ocean.

Species diversity is high in the scavenger guild on the Antarctic shelf (eastern Weddell Sea), in particular in crustaceans, i.e. in comparison with catches at shallower depths, such as those reported by Presler (1986) in the sublittoral of King George Island, who found five species of amphipods and two of isopods. Nemerteans, gastropods and echinoderms (asteroids, ophiuroids, echinoids and holothuroids) occur frequently in traps at depths of less than $100 \mathrm{~m}$ (e.g., Arnaud, 1970; Presler, 1986; De Broyer, unpublished). These groups were not represented in our catches at shelf, slope or abyssal depths except for five specimens of echinoderms and a single gastropod respectively found on the Weddell Sea shelf and slope.

The higher species richness seems also to hold true when eastern Weddell Sea shelf data are compared with other Antarctic catches at similar depths (e.g., Arnaud, 1970; Stockton, 1982; Nagata, 1986; Takeuchi et al., 2001). Arnaud (1970), for instance, found only a few tens of amphipods of two species (Abyssorchomene plebs and $A$. rossi), one specimen of two species of pycnogonid and of one species of fish at a depth of $320 \mathrm{~m}$ off Terre Adélie. Stockton (1982) recorded five species of amphipods (among which four were lysianassoids) and one mysid under the Ross Ice Shelf, while Nagata (1986) collected only four species of lysianassoids near Syowa Station (Lützow-Holm Bay, East Antarctica). Takeuchi et al. (2001) found seven species of amphipods (six lysianassoids, one eusirid), two of isopods (Cirolanidae, Gnathiidae), one mysid, three ostracods, one copepod, one leptostracan and two species of nototheniid fish in two trap sets on the shelf (171 and $353 \mathrm{~m}$ ) off Enderby Land. The general composition of the scavenger fauna thus appears quite similar between the eastern Weddell Sea and Enderby Land but more amphipods have been recorded in the former, which may at least partly be due to the larger number of trap sets analysed from the Weddell Sea (18 vs. 2).

In the Antarctic abyssal waters $(3000 \mathrm{~m}$ or deeper), the species richness of the scavenger guild appears to be less than documented from abyssal trap collections elsewhere in the world. The three 
Table 4

Amphipod species collected with the autonomous trap system and fish traps at depths greater than $1000 \mathrm{~m}$; occurrence by station and depth ranges

EASIZ I EASIZ II ANDEEP

\section{LYSIANASSOIDEA}

Lysianassidae and Uristidae

Abyssorchomene rossi (Walker, 1903)

Abyssorchomene scotianensis (Andres, 1983)

Abyssorchomene sp.A

Hippomedon sp.A

Hippomedon sp.B

Orchomenopsis cavimanus (Stebbing, 1888) var.A

Orchomenopsis n.sp.1

Parschisturella carinata (Schellenberg, 1926)

Pseudorchomene coatsi (Chilton, 1912)

Pseudorchomene n.sp.1

Stephonyx n.sp.1

Tryphosella of analogica (K.H. Barnard, 1932)

Tryphosella sp.C

Tryphosella sp.H

Tryphosella sp.I

Tryphosella $\mathrm{sp.J}$

"Tryphosella" n.sp.2

Tryphosinae gen. sp.A

\section{Alicellid family group}

Alicella n.sp. 1

Paralicella cf caperesca (Shulenberger and Barnard, 1976)

Paralicella n.sp.1

Eurytheneid family group

Eurythenes gryllus (Lichtenstein, 1822)

Hirondelleid family group

Hirondellea antarctica (Schellenberg, 1926)

Hirondellea n.sp.1

\section{Scopelocheridae}

Paracallisoma n.sp. 1

Scopelocheirus sp.A

IPHIMEDIOIDEA

Epimeriidae

Gen. sp.A

Iphimediidae

Iphimediella sp.A

\section{Stegocephalidae}

Gen. sp.C

Gen. sp.D
T6

T6

T6

T11-12

$46,100,114,131,139$

$\mathrm{T} 12$

100

100
1453-3739

1136

2280

2280

2280-2926

1453

1136-3070

1453

1136-3070

2926

1136-1453

1453-2280

1453

1136-1453

1136-1453

1136

2280

2280

2280

1453

2280

2926

2280-2754

(1)
$46,100,114$
ANDEEP trap sets close to or deeper than $3000 \mathrm{~m}$ provided only five species of necrophagous amphipods (Table 4) and Takeuchi et al. (2001) reported five amphipod and one isopod species. In comparison, the 44 trap sets at $3144-5940 \mathrm{~m}$ in the northeastern and tropical Atlantic Ocean analysed 
by Thurston (1990) yielded 15 different species (13 lysianassids, one scopelocheirid, one valettiettid), which constitute the largest abyssal trap record. Thurston's record, however, concerned several distinct abyssal plains and a much wider bathymetric range, prospected with many more trap sets.

On the other hand, the Antarctic slope $(1000-3000 \mathrm{~m})$ appears to be richer in scavenger species than elsewhere in the world at similar depth range. Thirty-one amphipod species have been collected (18 in the eastern Weddell Sea) vs., e.g., six amphipods species (all lysianassoids) on the Gulf of Biscay slope $(200-1800 \mathrm{~m}$ depth; Desbruyères et al., 1985), 11 amphipod species (nine lysianassoids, one eusirid, one tironid) found in baited traps by Vinogradov (1997) on the slope of the Norwegian Sea $(1690 \mathrm{~m})$ or five amphipod species (four lysianassoids, one epimeriid) collected by traps in the deep Cretan Sea (1511-2485 m depth; Jones et al., 2003).

It must be kept in mind in such comparisons that trap sampling is by no means quantitative, as remarked above, and that repeated sampling may yield more species.

The relation between species richness of necrophagous amphipods and depth is shown in Fig. 4. This figure clearly shows the variability of amphipod richness in coastal and shelf traps and its reduction from the shelf down-slope to the abyssal zone.

A number of species occurred on both the shelf and the slope, showing in some cases a quite extended level of bathymetry: Abyssorchomene rossi (219-1453 m), Eurythenes gryllus (5503789 m), Hippomedon sp.A (389-2009 m), Hirondellea antarctica (223-1136 m), Orchomenopsis cavimanus var.A (171-3070 m), Paracallisoma n.sp.1 (451-2280 m), Parschisturella carinata (219$1453 \mathrm{~m})$, Pseudorchomene coatsi (171-2280 m), Pseudorchomene n.sp.1 (798-1453 m), Stephonyx n.sp.1 (791-1453 m), Tryphosella of analogica (791-1453 m), Tryphosella sp.C (403-1136m), "Tryphosella" n.sp.2 (550-1453 m). In the Southern Ocean, E. gryllus is the only scavenger species found on the shelf, the slope and in the abyssal zone (see also Takeuchi et al., 2001). The latter species is a panoceanic bathyal (on seamounts, as shallow as $1440 \mathrm{~m}$, Bucklin et al., 1987), abyssal and hadal stenotherm species which can occur far above the sea floor (Thurston, 1990). It has been found in both polar regions at bathyal and abyssal depths (e.g., Bowman and Manning, 1972; Paul, 1973; Hargrave et al., 1992; De Broyer et al., 1999) and in bird stomachs (see Rauschert, 1985).

Arnaud (1970) observed some seasonality in the presence or abundance of several scavengers in the

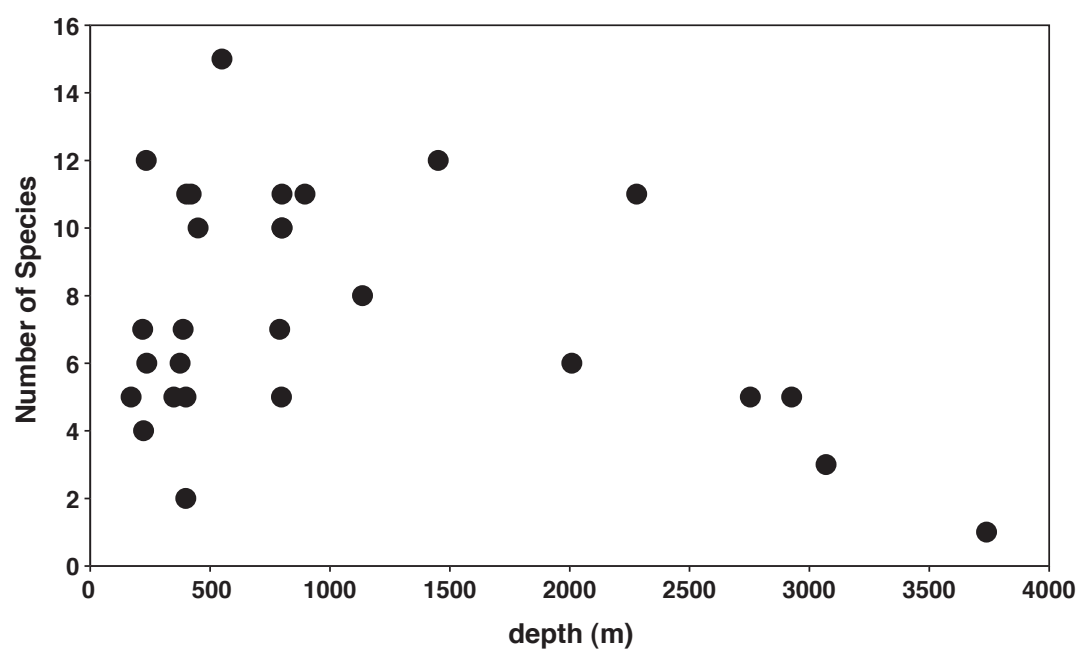

Fig. 4. Relation between species richness of necrophagous amphipods and depth. 
Terre Adélie catches (16-120 m): Waldeckia obesa was much more abundant in traps in winter than in summer and this could indicate a seasonal shift in diet or a migration. $W$. obesa was abundant in the Weddell Sea at shelf depths (171-895 m) during summer, suggesting migration or local movement as a most likely cause (see Bregazzi, 1972; Slattery and Oliver, 1986).

\subsection{Morphological adaptations to necrophagy}

Morphological analysis of the amphipod species collected in traps (Tables 3 and 4) has shown several types and degrees of adaptation to a necrophagous mode of life, thus confirming previous observations and interpretations (Dahl, 1979; Thurston, 1979; De Broyer, 1983). The typical eco-functional adaptations to necrophagy are summarised briefly in Table 5. No attempt is made here to document detailed differences in chemosensory organs (in particular callynophores; see Lowry, 1986; Meador, 1981) or mechanoreceptors (Klages et al., 2002). The focus is on the morphology of the mandible and the digestive tract.

Mandible morphology appears of primary importance in amphipod evolution in general and in the scavenger feeding types in particular (Dahl, 1979; De Broyer, 1985b; Barnard and Karaman, 1991; Watling, 1993). The evolutionary trend towards necrophagy is marked by several transformations of the mandible from the relatively basic type found in the opportunistic scavengers Orchomenopsis (e.g., O. obtusa; see Olerod, 1975) or Abyssorchomene to the types found in the deepsea species that are obligate scavengers Eurythenes,
Hirondellea and Paralicella (Dahl, 1979; Thurston, 1979; De Broyer, 1983). The following morphological transformations are considered adaptations to necrophagy:

- widening and sharpening of the incisor cutting edge;

- modification of the molar process from a relatively basic subcolumnar type with oval triturative surface (Orchomenopsis; see Olerod, 1975, Figs. 62 and 63) to the ridge-shaped type with elongate and reduced triturative surface (Abyssorchomene; see Dahl, 1979, Fig. 9), and ultimately to the non-triturative semitubular or "flap-like" setiferous molar found in Hirondellea or Eurythenes ,respectively (see Dahl, 1979, Figs. 5 and 6);

- transformation of the flat mandibular body found in Orchomenopsis to the strongly bowlshaped type found in Eurythenes or in Alicella (see De Broyer and Thurston, 1987). Together with the development of the raker spine row and the setal row prolonging the molar, and the widening of the incisor, this adaptation allows relatively large fragments or ships of food to be passed directly into the oesophagus (Thurston, 1979; De Broyer and Thurston, 1987). In common with the present deep sea material, all the abyssal scavenger species recorded by Thurston (1990) with the exception of Valettietta gracilis have a mandibular molar considerably modified from the basic gammaridean pattern.

Another important adaptation to necrophagy is the development of the storage capacity of either

Table 5

Morphological and physiological adaptations of scavenging amphipods with respect to behavioural constraints

\begin{tabular}{ll}
\hline Typical behavioural sequence of scavengers & Morphological and physiological adap \\
\hline Detecting and locating carrion source & $\begin{array}{l}\text { Chemosensory organs (callynophores) } \\
\text { Mechanoreception organs } \\
\end{array}$ \\
Arriving (quickly) to carrion & Good swimming ability \\
Ingesting (quickly) & Cutting mandible \\
Storing food & Enlarged foregut or midgut \\
Feeding opportunities & \\
Unpredictable & Resistance to starvation \\
& Reduced metabolism
\end{tabular}


the foregut, e.g., in Abyssorchomene or the midgut in Eurythenes, Hirondellea or Paralicella (Dahl, 1979; De Broyer, 1983). The "storing stomodeum" extending along the whole length of the pereion has been found in most lysianassid and uristid species we collected from shelf and deep-sea traps: Abyssorchomene, Hippomedon, Parschisturella, Pseudorchomene, Tryphosella, Uristes and Waldeckia. In Orchomenella (Orchomenopsis) it extends to the fourth pereionite.

Because several steps can be detected along the evolutionary pathway to the necrophagous mode of life in amphipods, it seems obvious from the morphological comparison of the different scavenger groups (in particular, eurytheneids, hirondelleids, alicellids, scopelocheiridae) that these adaptations arose independently several times during the evolution within the Lysianassoidea.

Previous studies have shown that baited traps attracted facultative, opportunistic scavengers as well as (presumed) obligate scavengers (e.g., Arnaud, 1970; Britton and Morton, 1994; Dauby et al., 2001a). The distinction between the two categories on the basis of morphological traits is by no means straightforward in amphipods. Mandible and gut morphology can help indicate scavenger status, but only within certain limitations. Eurytheneids, alicellids, and some Lysianassidae such as Waldeckia obesa are considered to be exclusive scavengers. Within the genus Hirondel$l e a$, for instance, which has a typical advanced scavenger-type mandible, deep-sea species probably are exclusive scavengers (Hessler et al., 1978). However, the shelf species $H$. antarctica is collected regularly in traps but is supposed to be mainly a micropredator on hydrozoans and sea anemones (Dauby et al., 2001a). Abyssorchomene plebs is frequently taken and sometimes is extremely abundant in bottom traps (e.g., RakusaSuszczewski, 1982; De Broyer and Klages, 1990). This species, as well as the less common A. rossi, are typical benthopelagic species that are also able to prey on copepods, salps and coelenterates in the water column (Dauby et al., 2001a). These Abyssorchomene species can feed on phytoplankton and microzooplankton organisms (Hopkins, 1985 , 1987) presumably aggregated prior to ingestion (see Riebesell et al., 1991) as these species have no filtering appendages.

Stomach content studies of animals from trap collections, as well as fatty acid and stable isotope analyses (Graeve et al., 2001; Nyssen et al., 2002), have revealed that the opportunistic scavengers may be primarily predators (e.g., Eusirus antarcticus, E. bouvieri, Hirondellea antarctica, Tryphosella murrayi) or mainly deposit feeders (e.g., Uristes gigas).

\subsection{Bathymetric distribution}

The bathymetric distribution of amphipods collected in traps in the eastern Weddell Sea is given in Fig. 5. The chart is not representative of the complete bathymetric distribution of these species as it does not include depth records from other gears.

In terms of bathymetric distribution, the trap results (Fig. 5) may indicate a faunal break for scavenger amphipods at a depth of about $800-1000 \mathrm{~m}$ in the eastern Weddell Sea that may be related to the shelf break depth. The same faunal limit is suggested by the scavenger isopod distribution (Fig. 6).

\subsection{Feeding experiments}

Table 6 gives the mean (and range) of the average feeding rates (in $\%$ dry weight day ${ }^{-1}$ ) measured during several experiments for the four studied species of Lysianassoidea. The egestion rate and digestion efficiency (both in \% of ingested food) are given for Waldeckia obesa. Available data for other Lysianassoidea are also reported.

It appears that feeding rates (averaged for each single experiment) encompass relatively large variations, ranging from $0.4 \%$ to $10.4 \% \mathrm{day}^{-1}$. These variations could be explained partly by the differences in the duration of the experiments (from 7 to 29 days, see Fig. 8), and by the fact that the number of experiments differed from species to species. The mean rate (averaged over all the different experiments), however, was not very different among the four species. The type of food given (squid vs. fish) influences this rate but the difference is not statistically significant. However, 


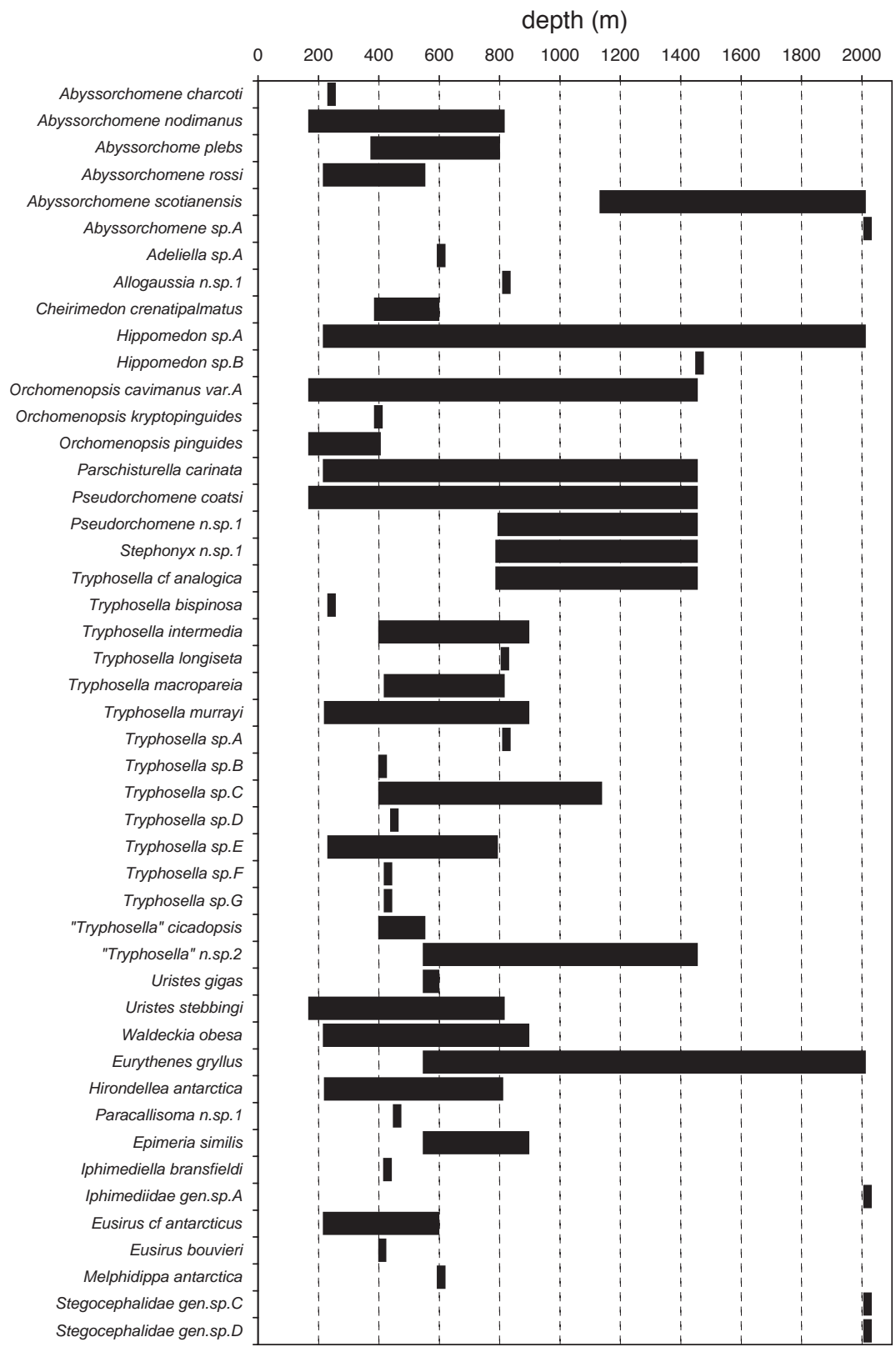

Fig. 5. Bathymetric distribution of amphipods collected with the autonomous trap system in the eastern Weddell Sea.

it has been shown (Moore, 1994) that Orchomenopsis zschaui digested soft tissues far more rapidly than epidermal material.

It is difficult to compare our estimates with literature data, as the latter are expressed in a different way, usually referring to meal size (vs. body mass) often inferred from in situ camera observations (e.g., Hargrave, 1985). This kind of estimate is made by offering scavengers a large quantity of bait and evaluating the ingested mass 


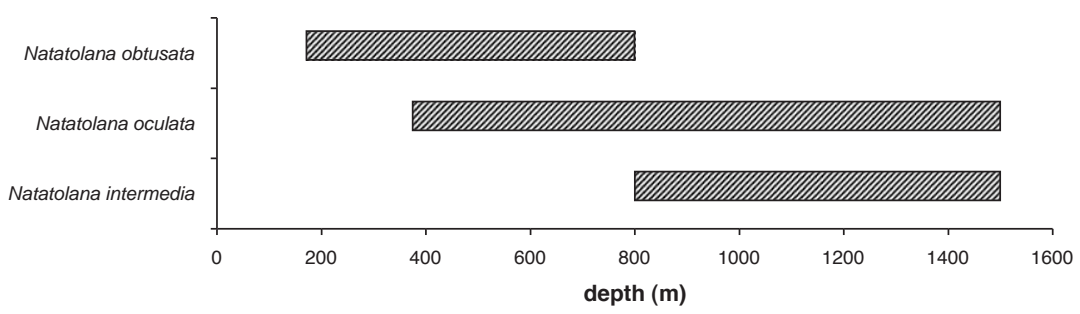

Fig. 6. Bathymetric distribution of cirolanid isopods collected with the autonomous trap system in the eastern Weddell Sea.

Table 6

Estimated and reported feeding rates of scavenging lysianassoid amphipods

\begin{tabular}{|c|c|c|c|c|c|c|c|}
\hline Species & $\begin{array}{l}\text { Given } \\
\text { food }\end{array}$ & $\begin{array}{l}\text { Number of } \\
\text { experiments }\end{array}$ & $\begin{array}{l}\text { Feeding rate } \\
(\% \text { body dry } \\
\left.\text { weight day }{ }^{-1}\right)\end{array}$ & $\begin{array}{l}\text { Meal size } \\
\text { (\% body } \\
\text { weight })\end{array}$ & $\begin{array}{l}\text { Egestion } \\
\text { rate } \\
\left(\% \text { food day }{ }^{-1}\right)\end{array}$ & $\begin{array}{l}\text { Digestion } \\
\text { efficiency } \\
(\% \text { food })\end{array}$ & Reference \\
\hline $\begin{array}{l}\text { Abyssorchomene } \\
\text { nodimanus }\end{array}$ & Squid & 5 & $4.1(2.5-5.1)$ & & & & this study \\
\hline Parschisturella carinata & Squid & 5 & $1.9(1.3-2.7)$ & & & & this study \\
\hline \multirow[t]{2}{*}{ Tryphosella murayi } & Fish & 8 & $2.1(0.4-4.5)$ & & & & this study \\
\hline & Squid & 14 & $1.4(0.9-4.5)$ & & & & this study \\
\hline \multirow[t]{2}{*}{ Waldeckia obesa } & Fish & 3 & $3.1(2.6-10.4)$ & & 33 & 67 & this study \\
\hline & Squid & 10 & $2.2(1.0-7.7)$ & & & & this study \\
\hline \multirow[t]{2}{*}{ Eurythenes gryllus } & Fish & & & $30-60$ & & & Hargrave (1985) \\
\hline & Fish & & & Up to 150 & & & Meador (1981) \\
\hline Anonyx sarsi & Squid & & & $10-37$ & & & Sainte-Marie (1987) \\
\hline Anonyx sp. & Squid & & & $10-18$ & & & Sainte-Marie et al. (1989) \\
\hline Orchomenella pinguis & Squid & & & $11-33$ & & & Sainte-Marie et al. (1989) \\
\hline Onisimus litoralis & Squid & & & $9-11$ & & & Sainte-Marie et al. (1989) \\
\hline Alicella gigantea & Fish & & & 12 & & & $\begin{array}{l}\text { De Broyer and } \\
\text { Thurston (1987) }\end{array}$ \\
\hline
\end{tabular}

over short periods of time. It does not take into account eventual periods of lower feeding activity, such as we observed in aquaria (see below), and is thus a measure of instantaneous ingestion capacity rather than an estimate of feeding rate over longer periods. This may explain the differences between the two sets of values.

The feeding rate of a group of individuals from a given species varied strongly from day to day (Fig. 7). Following starvation, lysianassids fed initially at a high rate (up to $15 \%$ day $^{-1}$ for some species), but afterwards this rate decreased gradually over a period of 4-8 days, depending on species. A subsequent increase in rate was observed, followed again by a decrease. This kind of rhythm, alternating between periods of intense feeding activity and periods of quasi-fasting, may be related to the time needed for digesting part of the ingested food or at least for clearance of the foregut. This behaviour could also suggest that tested scavenging amphipods are "topping up" whenever food is available, which would be consistent with a low level of dependency on necrophagy and a plug-flow feeding/digestion strategy (see Penry and Jumars, 1987). At the opposite, the gluttonous feeding reported, e.g., for Eurythenes or Anonyx in the literature (Table 6) is consistent with a high level of dependency on necrophagy and a batch feeding/digestion strategy. It must be pointed out, however, that on the basis 


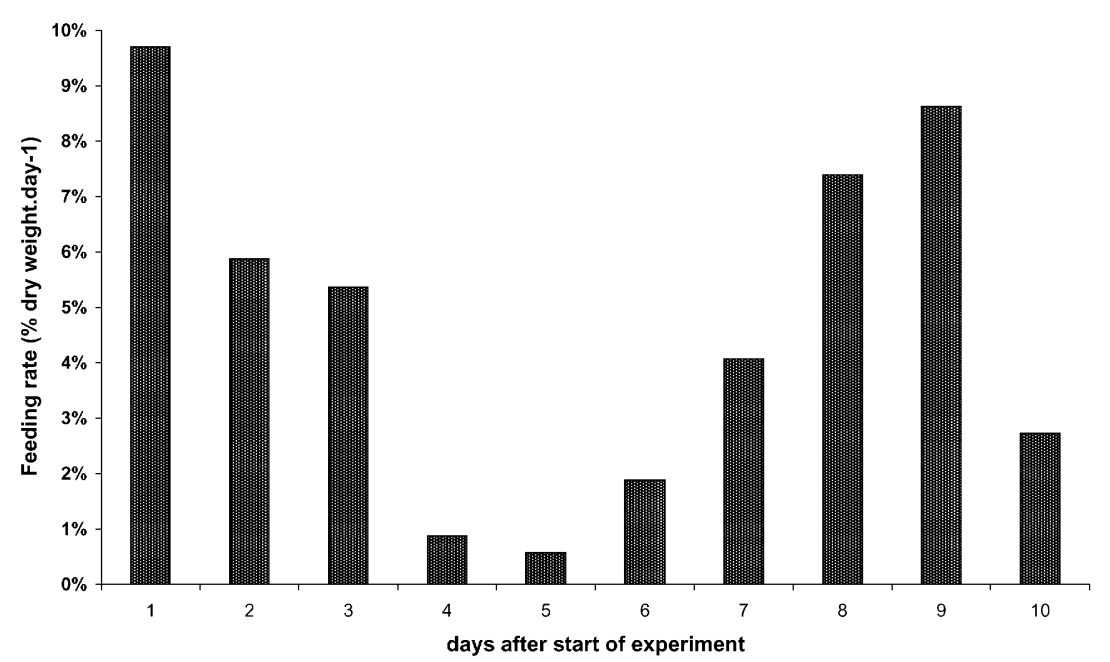

Fig. 7. Day-to-day variations of the mean feeding rate (in $\%$ dry weight day ${ }^{-1}$ ) of the scavenging lysianassid Abyssorchomene nodimanus (group of 50 individuals) during an aquarium experiment. Day 1 is the day following the starvation period.

of digestive tract observations (Dauby et al., 2001a), species such as Abyssorchomene nodimanus, Parschisturella carinata or Waldeckia obesa have been reported to be obligate - or at least preferential - necrophages.

On the other hand, feeding rates can vary by a factor of 4-5 among different experiments on the same species (Fig. 8). A huge food intake of bait may occur in the trap (see Table 6, meal size), that might be responsible for satiation of some collected animals and for a low feeding rate in aquarium experiments, even after a week-long starvation period. Animals maintained in aquaria can survive unfed for months (Chapelle et al., 1994).

The mean feeding rates, based on our experiments, vary between $1 \%$ and $5 \%$ dry weight day $^{-1}$, regardless of species. Very few data on digestion and assimilation rates of scavenging lysianassoid amphipods exist in the literature. Sainte-Marie (1992), assuming complete assimilation of the food bolus, calculated that for $E$. gryllus between 8.3 and 17.8 days would be required for complete digestion and assimilation of one meal. Hargrave et al. (1995) estimated from exponential curves fitted to decreases in gut contents of the same species that digestion would be $95 \%$ complete within $15-46 \mathrm{~h}$ in the Canada Basin, and within 99-255 h in the Nares and Sohm
Abyssal Plain. Comparing the organic matter in bait and in well-digested gut contents, they estimated a digestion efficiency of $85 \%$, which is not very different from the value we obtained for $W$. obesa, i.e. $67 \%$, using another method. Rapid digestion, associated with liquefaction of food, would enable amphipods to regain mobility as soon as possible after feeding, which is advantageous for these opportunistic feeders in food-poor environments (McKillup and McKillup, 1994; Hargrave et al., 1995).

Considering the numerous and diverse benthic fauna recorded on the Antarctic shelf (see Gutt et al., 2000), it appears that relatively few species, mostly lysianassoid amphipods, are attracted to baited traps. Similar observations were made in the high Arctic (Legezynska et al., 2000). Some species may occur in huge numbers (e.g., Slattery and Oliver (1986), who claimed 264,000 Abyssorchomene plebs in a single trap) indicative either of high local densities that are difficult to precisely evaluate, or of low chemosensory thresholds and high mobility allowing some species to congregate from large areas of bottom. The apparently significant role of the scavenger guild in the rapid dispersal of organic matter over the Antarctic shelf and deep-sea bottoms remains to be quantified more precisely. 


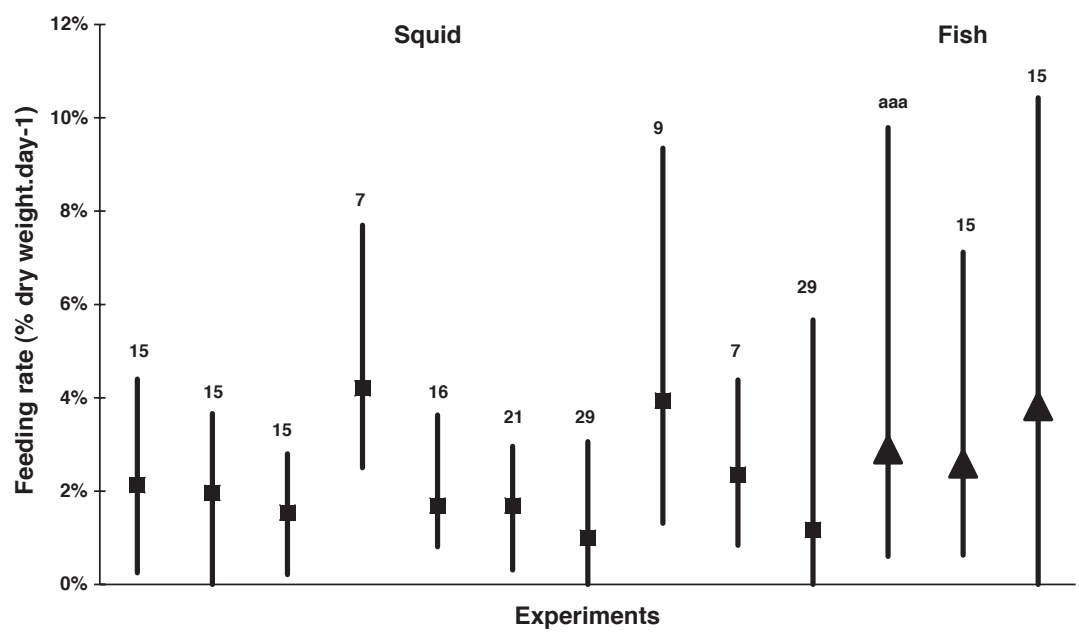

Fig. 8. Between-experiment variations of the feeding rate (in $\%$ dry weight day ${ }^{-1}$ ) of a scavenging lysianassid (Waldeckia obesa). Lines show the range of the day-to-day variations; symbols show the mean values (squares: fed with squid; triangles: fed with fish). Numbers above the lines give the durations (in days) of experiments.

\section{Acknowledgements}

This research was supported by the Scientific Research Programme on the Antarctic (Phases IV and $\mathrm{V}$ ) of the Belgian Federal Science Policy (contracts no. A4/DD/B02 and EV/36/24A). Samples were collected during the European 'Polarstern' Study (EPOS), sponsored by the European Science Foundation and the AlfredWegener-Institut für Polar- und Meeresforschung (AWI, Bremerhaven, Germany), during both EASIZ I and II campaigns (Ecology of the Antarctic Sea-Ice Zone), sponsored by AWI, and during the three consecutive cruises ANDEEP I, ANDEEP II (Antarctic Benthic Deep-Sea Biodiversity) and LAMPOS (Latin America Polarstern Study). We are indebted to the Officers and Crews of R.V. Polarstern for their skilful support of the sampling effort.

We would like to thank Profs. Wolf Arntz and Dieter Fütterer (AWI) and Prof. Angelika Brandt (University of Hamburg) for the invitation to participate in these cruises. Thanks are also due to Drs. Dieter Gerdes, Michael Klages, Thomas Brey, Julian Gutt (AWI), Brigitte Hilbig (University of Hamburg), as well as all colleagues who helped in collecting, sorting and analysing the samples.
Our colleagues from IRScNB, Drs. Yves Scailteur and Gauthier Chapelle are acknowledged for their efforts in performing feeding experiments. The ATS system could not be built without the savoir-faire of Camille Jamar. Thierry Kuyken and Angelino Meerhaeghe greatly helped in finalising figures and tables. We are grateful to Profs. Geoff Moore (Millport, UK), Mike Thurston (Southampton, UK), Wim Vader (Tromsø, Norway) and an anonymous referee who carefully and critically read and improved the manuscript.

This is ANDEEP contribution No. 20, and MARE publication No. 45.

\section{References}

Arnaud, P.M., 1970. Feeding and ecological significance of necrophagy among the benthic species of Antarctic coastal waters. In: Holdgate, M.W. (Ed.), Antarctic Ecology, vol. 1. Academic Press, London, pp. 259-267.

Arntz, W., Gutt, J. (Eds.), 1997. The Expedition ANTARKTIS XIII/3 (EASIZ I) of "Polarstern" to the Eastern Weddell Sea in 1996. Berichte zur Polarforschung 249, 1-148.

Arntz, W., Gutt, J. (Eds.), 1999. The expedition ANTARKTIS XV/3 (EASIZ II) of RV "Polarstern" in 1998. Berichte zur Polarforschung 301, 1-229.

Barnard, J.L., Karaman, G.S., 1991. The families and genera of marine gammaridean Amphipoda (except marine gammaroids). Records of the Australian Museum 13, 1-866. 
Berge, J., Vader, W., 2001. Revision of the amphipod (Crustacea) family Stegocephalidae. Zoological Journal of the Linnean Society 133, 531-592.

Berge, J., Vader, W., 2003. Stegocephalidae (Crustacea: Amphipoda) from Australia and New Zealand, with description of eight new species. Records of the Australian Museum 55, 85-112.

Bowman, T.E., 1974. The "sea flea" Dolobrotus mardenis n.gen., n.sp., a deep-water American lobster bait scavenger (Amphipoda, Eusiridae). Proceedings of the Biological Society of Washington 87, 129-138.

Bowman, T.E., Manning, R.B., 1972. Two arctic bathyal crustaceans: the shrimp Bythocaris cryonesus new species, and the amphipod Eurythenes gryllus, with in situ photographs from ice island T-3. Crustaceana 23, 187-201.

Brandt, A., De Broyer, C., Gooday, A.J., Hilbig, B., Thomson, M.R.A., 2003. Introduction to ANtarctic benthic DEEP-sea biodiversity (ANDEEP): colonization history and recent community patterns. Berichte zur Polar- und Meeresforschung 470, 45-49.

Bregazzi, P.K., 1972. Life cycle and seasonal movements of Cheirimedon femoratus (Pfeffer) and Tryphosella kergueleni (Miers) (Crustacea: Amphipoda). British Antarctic Survey Bulletin 30, 1-34.

Britton, J.C., Morton, B., 1994. Marine carrion and scavengers. Oceanography and Marine Biology: An Annual Review 32, 369-434.

Bruchhausen, P.M., Raymond, J.A., Jacobs, S.S., DeVries, A.L., Thorndike, E.M., Dewitt, H.H., 1979. Fish, crustaceans, and the sea floor under the Ross Ice Shelf. Science 203, 449-450.

Bucklin, A., Wilson Jr., R.D., Smith Jr., K.L., 1987. Genetic differentiation of seamount and basin populations of the deep-sea amphipod Eurythenes gryllus. Deep-Sea Research 34, 1795-1810

Chapelle, G., Peck, L.S., Clarke, A., 1994. Effects of feeding and starvation on the metabolic rate of the necrophagous Antarctic amphipod Waldeckia obesa (Chevreux, 1905). Journal of experimental marine Biology and Ecology 183, 63-76.

Chevreux, E., 1935. Amphipodes provenant des campagnes scientifiques du Prince Albert Ier de Monaco. Résultats des Campagnes scientifiques accomplies sur son Yacht par Albert Ier Prince Souverain de Monaco 90, 1-214.

Clarke, A., Johnston, N.M., 2003. Antarctic marine benthic biodiversity. Oceanography and Marine Biology: An Annual Review 41, 47-114.

Coleman, C.O., 1989a. On the nutrition of two Antarctic Acanthonotozomatidae (Crustacea: Amphipoda). Polar Biology 9, 287-294.

Coleman, C.O., 1989b. Gnathiphimedia mandibularis K.H. Barnard 1930, an Antarctic amphipod (Acanthonotozomatidae, Crustacea) feeding on Bryozoa. Antarctic Science 1, 343-344.

Dahl, E., 1979. Deep-sea carrion feeding amphipods: evolutionary patterns in niche adaptation. Oikos 33, 167-175.
Dauby, P., Scailteur, Y., De Broyer, C., 2001a. Trophic diversity within eastern Weddell Sea amphipod community. Hydrobiologia 443, 69-86.

Dauby, P., Scailteur, Y., Chapelle, G., De Broyer, C., 2001 b. Potential impact of the main benthic amphipods on eastern Weddell Sea shelf ecosystem (Antarctica). Polar Biology 24, 657-662.

De Broyer, C., 1983. Recherches sur la systématique et l'évolution des crustacés amphipodes gammarides antarctiques et subantarctiques. Ph.D. Thesis, Catholic University, Louvain, Belgium, unpublished.

De Broyer, C., 1985a. Amphipodes lysianassoides nécrophages des Îles Kerguelen (Crustacea): 1. Orchomenella guillei n.sp. Bulletin du Muséum national d'Histoire naturelle (Série 4) 7, 205-217.

De Broyer, C., 1985b. Description de Falklandia gen. n. de l'Océan Austral et définition des Lysianassoidea uristidiens (Crustacea, Amphipoda). Zoologica Scripta 14, 303-312.

De Broyer, C., Jazdzewski, K., 1993. Contribution to the marine biodiversity inventory. A checklist of the Amphipoda (Crustacea) of the Southern Ocean. Documents de Travail de l'Institut Royal des Sciences Naturelles de Belgique 73, 1-154.

De Broyer, C., Klages, M., 1990. Studies on amphipod biology. In: Arntz, W., Ernst, W., Hempel, I., (Eds.), The Expedition ANTARKTIS VII/4 (EPOS Leg 3) and VII/5 of RV "Polarstern" in 1989. Berichte zur Polarforschung 68, 113-115.

De Broyer, C., Thurston, M.H., 1987. New Atlantic material and redescription of the type specimen of the giant abyssal amphipod Alicella gigantea Chevreux (Crustacea). Zoologica Scripta 16, 335-350.

De Broyer, C., Rauschert, M., Chapelle, G., 1997. Trophodynamics, biodiversity and gigantism of the amphipod crustacean taxocoenoses. In: Arntz, W., Gutt, J., (Eds.), The Expedition ANTARKTIS XIII/3 (EASIZ I) of "Polarstern" to the Eastern Weddell Sea in 1996. Berichte zur Polarforschung 249, 76-79.

De Broyer, C., Rauschert, M., Scailteur, Y., 1999. Structural and ecofunctional biodiversity of the benthic amphipod taxocoenoses. In: Arntz, W., Gutt, J., (Eds.), The expedition ANTARKTIS XV/3 (EASIZ II) of RV "Polarstern" in 1998. Berichte zur Polarforschung 301, 163-174.

De Broyer, C., Dauby, P., Nyssen, F., Martin, P., 2003. Biodiversity, molecular phylogeny and trophodynamics of amphipod crustaceans in the Antarctic deep-sea. Berichte zur Polar- und Meeresforschung 470, 81-86.

Desbruyères, D., Geistdoerfer, P., Ingram, C.L., Khripounoff, A., Lagardère, J.P., 1985. Répartition des populations de l'épibenthos carnivore. In: Laubier, L., Monniot, C. (Eds.), Peuplements profonds du Golfe de Gascogne, Campagnes BIOGAS. IFREMER, Brest, pp. 233-251.

Gage, J.D., Tyler, P.A., 1991. Deep-sea biology: a natural history of organisms at the deep-sea floor. Cambridge University Press, Cambridge, 504pp.

Graeve, M., Dauby, P., Scailteur, Y., 2001. Combined lipid, fatty acid and digestive tract content analyses: a penetrating 
approach to estimate feeding modes of Antarctic amphipods. Polar Biology 24, 853-862.

Guennegan, Y., Martin, V., 1985. Techniques de prélèvements. In: Laubier, L., Monniot, C. (Eds.), Peuplements Profonds du Golfe de Gascogne. IFREMER, Brest, pp. 571-602.

Gutt, J., Sirenko, B.I., Arntz, W.E., Smirnov, I.S., De Broyer, C., 2000. Biodiversity of the Weddell Sea: macrozoobenthic species (demersal fish included) sampled during the expedition ANT XIII/3 (EASIZ I) with RV "Polarstern". Berichte zur Polarforschung 372, 1-103.

Hargrave, B.T., 1985. Feeding rates of abyssal scavenging amphipods (Eurythenes gryllus) determined in situ by timelapse photography. Deep-Sea Research 32, 443-450.

Hargrave, B.T., Germain, P., Philippot, J.-C., Hemon, G., Smith, J.N., 1992. Stable elements and ${ }^{210} \mathrm{Po}$ in the deep-sea amphipod Eurythenes gryllus. Deep-Sea Research 39, $37-44$.

Hargrave, B.T., Phillips, G.A., Prouse, N.J., Cranford, P.J., 1995. Rapid digestion and assimilation of bait by the deepsea amphipod Eurythenes gryllus. Deep-Sea Research Part I 42, 1905-1921.

Hessler, R.R., Ingram, C.L., Yayanos, A.A., Burnett, B.R., 1978. Scavenging amphipods from the floor of the Philippine Trench. Deep-Sea Research 25, 1029-1047.

Hopkins, T.L., 1985. Food web of an Antarctic midwater ecosystem. Marine Biology 89, 197-212.

Hopkins, T.L., 1987. Midwater food web in McMurdo Sound, Ross Sea, Antarctica. Marine Biology 96, 93-106.

Hurley, D.E., 1965. A common but hitherto undescribed species of Orchomenella (Crustacea Amphipoda: family Lysianassidae). Transactions of the Royal Society of New Zealand, Zoology 6, 107-113.

Isaacs, J.D., Schwartzlose, R.A., 1975. Active animals on the deep-sea floor. Scientific American 233, 84-91.

Jones, E.G., Tselepides, A., Bagley, P.M., Collins, M.A., Priede, I.G., 2003. Bathymetric distribution of some benthic and benthopelagic species attracted to baited cameras and traps in the deep eastern Mediterranean. Marine Ecology Progress Series 251, 75-86.

Klages, M., Muyakshin, S., Soltwedel, T., Arntz, W.E., 2002. Mechanoreception, a possible mechanism for food fall detection in deep-sea scavengers. Deep-Sea Research I 49, 143-155.

Legezynska, J., Weslawski, J.M., Presler, P., 2000. Benthic scavengers collected by baited traps in the high Arctic. Polar Biology 23, 539-544.

Lipps, J.H., Ronan Jr., T.E., Delaca, T.E., 1979. Life below the Ross Ice Shelf, Antarctica. Science 203 (4379), 447-449.

Lowry, J.K., 1986. The callynophore, a eucaridan/peracaridan sensory organ prevalent among the Amphipoda (Crustacea). Zoologica Scripta 15, 333-349.

Lowry, J.K., Stoddart, H.E., 1989. Stephonyx, a new, widespread genus of lysianassoid Amphipoda. Zoologica Scripta 18, 519-525.

Lowry, J.K., Stoddart, H.E., 1994. Crustacea Amphipoda: lysianassoids from the tropical western South Pacific Ocean. In: Crosnier, A., (Ed.), Résultats des Campagnes
MUSORSTOM 12, vol. 161. Mémoires du Muséum national d'Histoire naturelle, Paris, pp. 127-233.

McKillup, S.C., McKillup, R.V., 1994. The decision to feed by a scavenger in relation to the risks of predation and starvation. Oecologia 97, 41-48.

Meador, J.P., 1981. Chemoreception and food-finding abilities of a lysianassid amphipod. Ph.D. Thesis, San Diego State University, US, unpublished.

Moore, P.G., 1994. Observations on the behaviour of the scavenging lysianassoid Orchomene zschaui (Crustacea: Amphipoda) from South Georgia (South Atlantic). Marine Ecology Progress Series 113, 29-38.

Nagata, K., 1986. Amphipod crustaceans found near Syowa Station, Antarctica. Memoirs of the National Institute of Polar Research 40, 249-258 (special issue).

Nyssen, F., Brey, T., Lepoint, G., Bouquegneau, J.M., De Broyer, C., Dauby, P., 2002. A stable isotope approach to the eastern Weddell Sea trophic web: focus on benthic amphipods. Polar Biology 25, 280-287.

Olerod, R., 1975. The mouthparts in some North Atlantic species of the genus Orchomene Boeck (Crustacea, Amphipoda). Zoologica Scripta 4, 205-216.

Paul, A.Z., 1973. Trapping and recovery of living deep-sea amphipods from the Arctic Ocean floor. Deep-Sea Research 20, 289-290.

Penry, D.L., Jumars, P.A., 1987. Modeling animal guts as chemical reactors. The American Naturalist 129, 69-96.

Presler, P., 1986. Necrophagous invertebrates of the Admiralty Bay of King George Island (South Shetland Islands, Antarctica). Polish Polar Research 7, 25-61.

Rakusa-Suszczewski, S., 1982. The biology and metabolism of Orchomene plebs (Hurley, 1965) (Amphipoda: Gammaridea) from McMurdo Sound, Ross Sea, Antarctic. Polar Biology 1, 47-54.

Rauschert, M., 1985. Eurythenes gryllus (Lichtenstein) (Crustacea, Amphipoda) in der marinen Fauna von King George (Südshetlandinseln, Antarktis). Milu 6, 319-324.

Richard, J., 1934. Liste générale des stations des campagnes scientifique du Prince Albert de Monaco avec notes et observations. Résultats des Campagnes scientifiques accomplies sur son Yacht par Albert Ier Prince Souverain de Monaco 89, 1-348.

Riebesell, U., Schloss, I., Smetacek, V., 1991. Aggregation of algae released from melting sea ice: implications for seeding and sedimentation. Polar Biology 11, 239-248.

Sainte-Marie, B., 1987. Meal size and feeding rate of the shallow-water lysianassid Anonyx sarsi (Crustacea: Amphipoda). Marine Ecology Progress Series 40, 209-219.

Sainte-Marie, B., 1992. Foraging of scavenging deep-sea lysianassoid amphipods. In: Rowe, G.T., Pariente, V. (Eds.), Deep-Sea Food Chains and Global Carbon Cycle. Kluwer Academic, The Netherlands, pp. 105-124.

Sainte-Marie, B., Hargrave, B.T., 1987. Estimation of scavenger abundance and distance of attraction to bait. Marine Biology 94, 431-444.

Sainte-Marie, B., Percy, J.A., Shea, J.R., 1989. A comparison of meal size and feeding rate of the lysianassid amphipods 
Anonyx nugax, Onisimus (=Pseudalibrotus) litoralis and Orchomenella pinguis. Marine Biology 102, 361-368.

Slattery, P.N., Oliver, J.S., 1986. Scavenging and other feeding habits of lysianassid amphipods (Orchomene spp.) from McMurdo Sound, Antarctica. Polar Biology 6, $171-177$.

Stockton, W.L., 1982. Scavenging amphipods from under the Ross Ice Shelf, Antarctica. Deep-Sea Research 29, 819-835.

Takeuchi, I., Watanabe, K., Tanimura, A., Fukuchi, M., 2001. Assemblages of necrophagous animals off Enderby Land, East Antarctica. Polar Biology 24, 650-656.

Thurston, M.H., 1979. Scavenging abyssal amphipods from the North-East Atlantic Ocean. Marine Biology 51, 55-68.
Thurston, M.H., 1990. Abyssal necrophagous amphipods (Crustacea: Amphipoda) in the northeast and tropical Atlantic Ocean. Progress in Oceanography 24, 257-274.

Vader, W., 1972. Notes on Norwegian marine Amphipoda. 5. New records of Leptamphopus sarsii (Calliopiidae). Sarsia $50,25-28$.

Vinogradov, G., 1997. Scavenger amphipods (Amphipoda Gammaridea, Crustacea) of the continental slope of the Norwegian Sea. In: Benthos of the Northern Seas of Eurasia. VNIRO, Moscow (in Russian).

Walker, A.O., 1907. Crustacea. III. Amphipoda. National Antarctic Expedition 1901-1904. Natural History 3, 1-38.

Watling, L.E., 1993. Functional morphology of the amphipod mandible. Journal of Natural History 27, 837-849. 